\title{
Determinant Implementasi Informasi Akuntansi Usaha Kecil serta Menengah di Kabupaten Banjarnegara
}

\author{
Alifah Nurfarindha ${ }^{1}$, Heri Yanto ${ }^{2}$ \\ Universitas Negeri Semarang ${ }^{1,2}$ \\ alifahnurfarindha@gmail.com ${ }^{1}$, heri.yanto@mail.unnes.ac.id ${ }^{2}$
}

$\begin{array}{ll}\text { *Corresponding Author } \\ \text { Diajukan } & : \text { 25 Januari } 2022 \\ \text { Disetujui } & : 30 \text { Februari } 2022 \\ \text { Dipublikasi } & : 1 \text { Februari } 2022\end{array}$

\section{ABSTRACT}

This study examines the effect of SMEs' perceptions, education level, accounting knowledge, accounting training on the application of accounting information by small and medium enterprises. This study aims to test empirically the effect of perception, education, accounting knowledge and accounting training of SMEs on the application of accounting information. This study uses a quantitative method with purposive sampling technique using the Slovin formula. The data used in this study is primary data obtained from online and offline questionnaires distributed to 104 SMEs throughout Banjarnegara Regency using the purposive sampling method with the slovin formula. From the results of this study, it can be concluded that there is a significant influence between the perception of Small and Medium Enterprises actors and the level of education on the application of accounting information in Small and Medium Enterprises. And there is no significant effect between accounting knowledge and accounting education on the application of accounting information in small and medium enterprises. Suggestions related to the results of this study are: several parties with an interest in improving small and medium enterprises in Banjarnegara Regency, especially the Ministry of Industry, Trade, Cooperatives and Small and Medium Enterprises in Banjarnegara Regency to provide advice and guidelines for the application of accounting information in the operation of a business because accounting information is very necessary in managing a business, do not see that the business is still small or large.

Keywords: Application of Accounting Information, Small and Medium Enterprises

\section{PENDAHULUAN}

Salah satu sektor yang memajukan ekonomi suatu bangsa adalah Usaha Kecil Menengah (UKM), karena pada UKM membutuhkan dan menyerap tenaga kerja yang banyak, meningkatkan nilai PDB (ProdukDomestik Bruto), serta meningkatkan kegiatan ekspor impor. Kontribusi Usaha Kecil serta Menengah terhadap ekonomi pada suatu negara memiliki dampak yang positif. Maka jika semakin banyak Usaha Kecil serta Menengah yang berkontribusi semakin meningkat ekonomi pada suatu Negara (Sih Darmi Astuti \& J.Widiatmoko, 2003)

Jumlah UKM pada Kabupaten Banjarnegara menurut data dari disperindagkop tahun 2021 adalah sebanyak 28.187. Dari data tersebut ada beberapa UKM dari Banjarnegara yang sudah mendunia dengan cara melakukan kegiatan impor ke luar negeri. Namun kenyataannya, masalah utama dalam UKM adalah dalam bidang pengelolaan keuangannya, misalnya tidak bisa mengelola keuangannya dengan baik dan efektif. Untuk itu salah satu caranya yaitu pelaku 
Usaha Kecil Menengah dituntut untuk memperbaiki informasi akuntansi, hal tersebut merupakan satu cara agar UKM dapat tumbuh dan berkembang. Informasi akuntansi bermanfaat untuk perusahaan untuk memecahkan masalah dan alat pengambilan keputusan.

Menurut data BPS selama 10 tahun terakhir hingga tahun 2017 di Provinsi Jawa Tengah, jumlah badan usaha atau badan usaha meningkat sebesar $13,06 \%$ yaitu sebesar 4,17 juta badan usaha atau badan usaha. Dari 4,17 juta usaha atau 98,98\% di antaranya adalah usaha mikro dan kecil. Dan sisanya 1,02\% Usaha Menengah dan Besar. Sedangkan data dari Kementerian Perindustrian dan Perdagangan dan UKM Kab. Banjarnegara jumlah UKM di lingkungan sekitar. Banjarnegara berkembang setiap tahun . Dapat dilihat pada grafik di bawah ini:

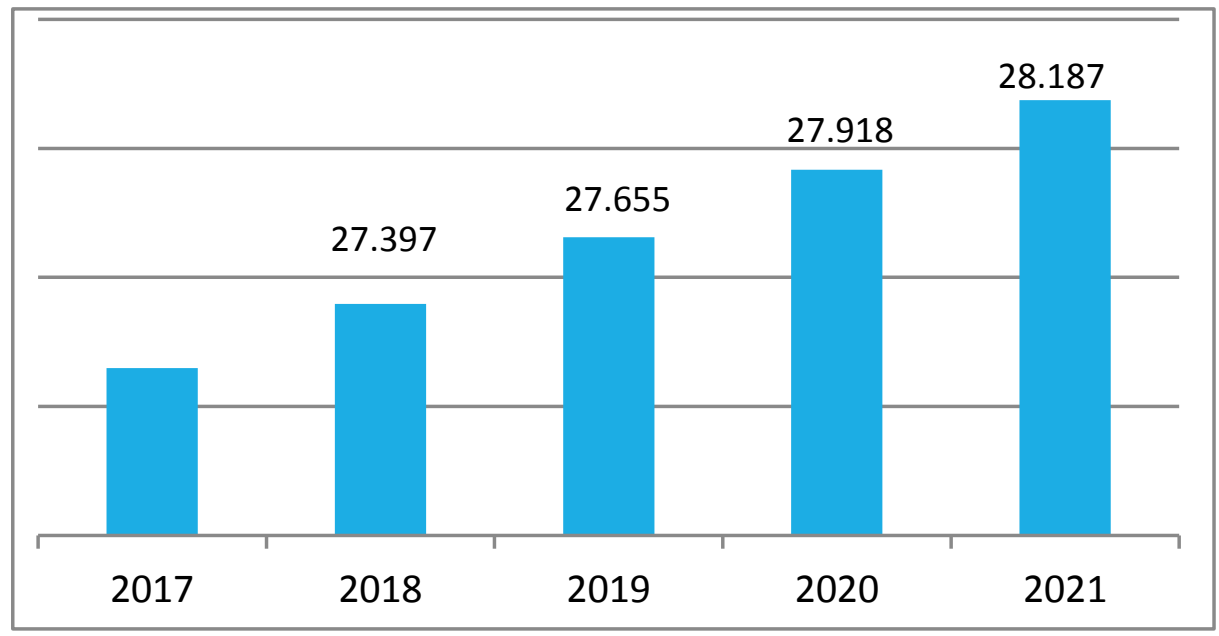

Gambar 1. Jumlah UKM Kabupaten Banjarnegara Tahun 2017-2021

Sumber: Dinas Perindagkop dan UKM Kabupaten Banjarnegara, 2020

Berdasarkan hasil wawancara, survey dan pengamatan di lapangan di UKM Kabupaten Banjarnegara, antara lain UKM Rumah Mocaff dan UKM Kopi Warung Stasiun usaha yang bergerak pada bidang produksi pangan pada tanggal 15 dan 16 September 2020 didapatkan beberapa permasalahan pada UKM yaitu adanya persepsi pelaku UKM atas akuntansi masih kurang, tingkat pendidikan manajer atau pemilik yang rendah, pengetahuan akuntansi yang masih kurang dari pelaku UKM serta manajer/pegawai tidak ingin melakukan pelatihan akuntansi dikarenakan sulit untuk mempelajari akuntansi.

Dari permasalahan-permasalahan tersebut memiliki pengaruh yang besar dan berdampak pada berjalanya usaha tersebut tentunya akan memengaruhi dalam bidang keuangan. Pada penerapan informasi akuntansi UKM masih jauh tertinggal disbanding sektor lain. Padahal, perusahaan yang mampu bersaing yaitu perusahaan yang mampu berkompetitif dengan lain.

Dari hasil penjelasan di atas, penelitian ini bertujuan menganalisis pengaruh persepsi pelaku UKM, pendidikan, pengetahuan akuntansi dan pelatihan akuntansi terhadap penerapan informasi akuntansi UKM

Penelitian ini akan dilaksanakan pada pelaku UKM di Kabupaten Banjarnegara sebagian besar jenis UKM nya adalah pada bidang usaha dagang. Serta ada beberapa bidang usaha lain antara lain bidang produksi dan jasa.

\section{STUDI LITERATUR}

\section{A. Penelitian Terdahulu}




\begin{tabular}{|c|c|c|c|c|}
\hline Nomor & $\begin{array}{c}\text { Nama } \\
\text { Peneliti dan } \\
\text { Tahun }\end{array}$ & $\begin{array}{c}\text { Judul } \\
\text { Penelitian }\end{array}$ & Variable & Hasil \\
\hline 1 & $\begin{array}{l}\text { Yuli } \\
\text { Setyawati, } \\
\text { Sigit } \\
\text { Hermawan } \\
(2018)\end{array}$ & $\begin{array}{l}\text { Persepsi Pemilik } \\
\text { dan Pengetahuan } \\
\text { Akuntansi Pelaku } \\
\text { Usaha UMKM } \\
\text { Atas Penyusunan } \\
\text { Laporan Keuangan }\end{array}$ & $\begin{array}{l}\text { Persepsi Pemilik } \\
\text { (X1), } \\
\text { Pengetahuan } \\
\text { Akuntansi (X2), } \\
\text { Laporan } \\
\text { Keuangan (Y) }\end{array}$ & $\begin{array}{lr}\text { Persepsi dan } & \text { pemilik } \\
\text { berpengaruh } & \text { positif } \\
\text { terhadap } & \text { laporan } \\
\text { keuangan } & \\
\end{array}$ \\
\hline 2 & $\begin{array}{l}\text { Rini Frima, } \\
\text { Sarmiadi } \\
\text { (2018) }\end{array}$ & $\begin{array}{lr}\text { Pengaruh } & \text { Tingkat } \\
\text { Pendidikan } & \\
\text { Pemilik } & \\
\text { Terhadap } & \\
\text { Penggunaan } & \\
\text { Informasi } & \\
\text { Akuntansi } & \text { (Studi } \\
\text { Padar } & \text { UMKM } \\
\text { dengan Kluster } \\
\text { Menengah di Kota } \\
\text { Padang) } & \\
\end{array}$ & \begin{tabular}{l}
\multicolumn{1}{c}{ Tingkat } \\
Pendidikan (X1), \\
Penggunaan \\
Informasi \\
Akuntansi (Y)
\end{tabular} & $\begin{array}{l}\text { Tingkat pendidikan } \\
\text { memiliki pengaruh } \\
\text { yang positif terhadap } \\
\text { informasi akuntansi }\end{array}$ \\
\hline 3 & $\begin{array}{l}\text { Putu Diah } \\
\text { Asrida dan Ni } \\
\text { Wayan Widi } \\
\text { Astuti (2018) }\end{array}$ & $\begin{array}{l}\text { Pengaruh } \\
\text { Pengetahuan } \\
\text { Akuntansi terhadap } \\
\text { Penggunaan } \\
\text { Informasi } \\
\text { Akuntansi dengan } \\
\text { Ketidakpastian } \\
\text { Lingkungan } \\
\text { sebagai } \\
\text { Pemoderasi }\end{array}$ & $\begin{array}{l}\text { Pengetahuan } \\
\text { Akuntansi (X1), } \\
\text { Penggunaan } \\
\text { Informasi } \\
\text { Akuntansi (Y), } \\
\text { Ketidakpastian } \\
\text { Lingkungan (M) }\end{array}$ & $\begin{array}{l}\text { Pengetahuan } \\
\text { akuntansi memiliki } \\
\text { pengaruh terhadap } \\
\text { penggunaan informasi } \\
\text { akuntansi serta } \\
\text { ketidakpastian } \\
\text { lingkungan } \\
\text { memperkuat pengaruh } \\
\text { pengetahuan } \\
\text { akuntansi terhadap } \\
\text { penggunaan informasi } \\
\text { akuntani }\end{array}$ \\
\hline 4 & $\begin{array}{l}\text { Dian } \\
\text { Efriyenty } \\
(2020)\end{array}$ & $\begin{array}{lr}\text { Analisis } & \text { Faktor- } \\
\text { Faktor rang } \\
\text { Mempengaruhi } \\
\text { Penggunaan } \\
\text { Informasi } \\
\text { Akuntansi pada } \\
\text { UMKM } \\
\text { Batam } & \\
\end{array}$ & $\begin{array}{l}\text { Tingkat } \\
\text { Pendidikan (X1), } \\
\text { Lama Pelatihan } \\
\text { bisnis (X2), } \\
\text { Akuntansi (X3), } \\
\text { Penggunaan } \\
\text { informasi } \\
\text { akuntansi (Y) }\end{array}$ & $\begin{array}{lr}\text { Tingkat pendidikan, } \\
\text { lama pelatihan bisnis } \\
\text { dan } & \text { akuntansi } \\
\text { berpengruh } & \text { secara } \\
\text { signifikan } & \text { ada } \\
\text { penggunaan } & \text { informasi } \\
\text { akuntansi } & \end{array}$ \\
\hline 5 & $\begin{array}{l}\text { Ricardo } \\
\text { Vinicius Dias } \\
\text { Jordao, Jorge } \\
\text { Novas and } \\
\text { Vipin Gupta } \\
\text { (2019) }\end{array}$ & $\begin{array}{l}\text { The Role of } \\
\text { Knowledge Based } \\
\text { Networks in the } \\
\text { Intellectual Capital } \\
\text { and Organizational } \\
\text { Performance of } \\
\text { Small and Medium } \\
\text { Sized Enterprises } \\
\text { (2019) }\end{array}$ & $\begin{array}{l}\text { Intellectual } \\
\text { Capital (X1) } \\
\text { Organizational } \\
\text { Performance } \\
\text { (X2), Small and } \\
\text { Medium Sizes } \\
\text { Enterprises (Y) }\end{array}$ & $\begin{array}{l}\text { Intellectual Capital } \\
\text { berpengaruh terhadap } \\
\text { Small And } \\
\text { Medium Sized } \\
\text { Enterprises } \\
\text { Organizational } \\
\text { Performance } \\
\text { berpengaruh terhadap } \\
\text { Small And Medium- } \\
\text { Sized Enterprises }\end{array}$ \\
\hline
\end{tabular}

\section{Penerapan Informasi Akuntansi}

Pada UKM wajib menerapkan informasi akuntansi dengan berpedoman pada 
Owner: Riset \& Jurnal Akuntansi

e -ISSN : 2548-9224 | p-ISSN : 2548-7507

Volume 6 Nomor 1, Januari 2022

Undang-undang dan SAK sesuai yang berlaku di Indonesia. Pengukurannya menggunakan 4 skala likert.

\section{Persepsi Pelaku UKM}

Persepsi pelaku UKM tentang akuntansi yaitu bagaimana pendapat terhadap akuntansi sebagai bagian dari kegiatan usaha, apakah membantu dalam mengambil keputusan atau tidak. Indikator yang digunakan yaitu kegiatan seleksi oleh pelaku UKM mengenai accounting, pemahaman pada pelaku. Pengukurannya menggunakan 4skala likert.

\section{Pendidikan}

Pendidikan adalah elemen kunci dari menentukan kemampuan bekerja serta mempengaruhi kemampuan pengetahuan inividu. Oleh sebab itu, pendidikan tinggi manajer manajer mempengaruhi pengetahuan akuntansi dan dapat mempengaruhi penerapan akuntansi yang menjalankan perusahaannya. Pendidikan yang dimiliki pelaku UKM memberikan pengetahuan tambahan untuk berinovasi dan mengembangkan bisnis mereka.

\section{Pengetahuan Akuntansi}

Pengetahuan akuntansi adalah suatu jenis informasi yang dianggap sebagai keaslian, fakta atau kewajiban informasi, disusun secara logis dan teratur, dengan tujuan memberikan informasi yang berkaitan dengan proses pencatatan, pengelompokan, dan penghitungan peristiwa ekonomi yang diperlukan untuk pengambilan keputusan.

\section{Pelatihan Akuntansi}

Pelatihan akuntansi merupakan sebuah usaha untuk menambah pengetahuan dan wawasan yang lebih dalam pada bidang akuntansi. Indikatornya yaitu pelaku UKM pernah mengikuti pelatihan akuntansi atau belum, pelatihan informasi akuntansi berguna bagi perusahaan dan mempraktikkan pelatihan informasi akuntansi dalam perusahaan. Pengukurannya menggunakan 4 skala likert

\section{B. Kerangka Berfikir}

Kerangka pemikiran yaitu jalan yang sederhana untuk menjelaskan antar variabel penelitian. Dalam penelitian ini akan dijelaskan mengenai Pengaruh Persepsi Pelaku Ukm, Pendidikan, Pengetahuan Akuntansi dan Pelatihan Akuntansi terhadap Penerapan Informasi akuntansi.

Berikut merupakan kerangka teoritis penelitian:

\section{Tabel 2.1 Kerangka Pemikiran}




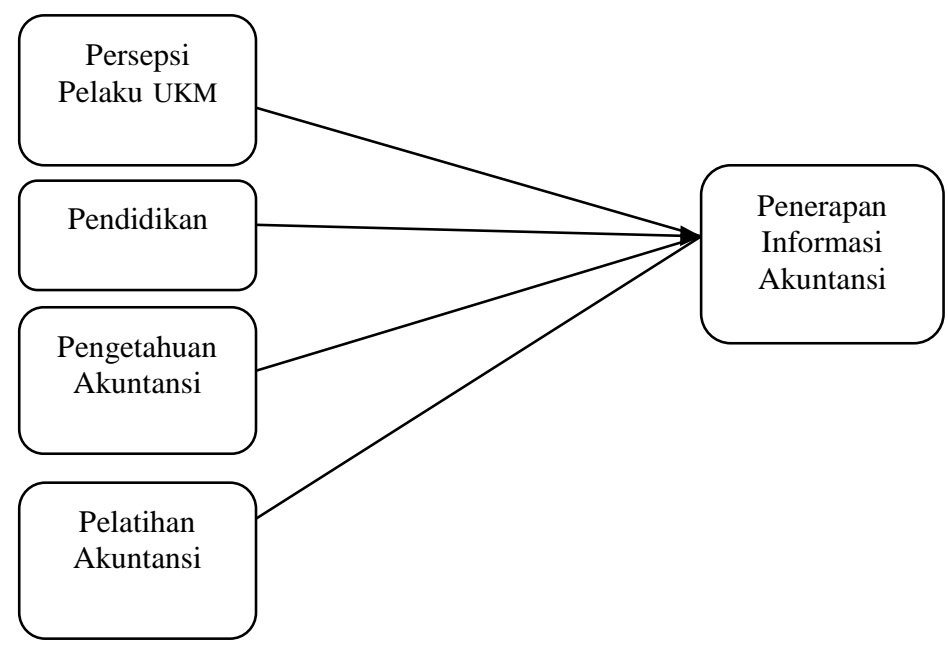

\section{Population dan Sample}

\section{METODE}

Population pada penelitian ini merupakan seluruh UKM yang terdapat pada Kabupaten Banjarnegara. Berdasarkan data Kementrian Perindustrian, Perdagangan, Koperasi serta UKM, UKM Kabupaten Banjarnegara pada tahun 2021 sebanyak 28.187. Penelitian ini memakai rumus Slovin. Sample untuk penelitian yang diperoleh dengan menggunakan rumus Slovin.

$$
\mathrm{n}=\frac{N}{N(D)^{2}+1}
$$

Ket:

$\mathrm{n}=$ Banyak sample

$\mathrm{N}=$ Banyak population

$\mathrm{D}=$ Tingkat /ketepatan yang diinginkan

Dalam penelitian ini mengambil sample sejumlah:

$$
\begin{aligned}
& \mathrm{n}=\frac{28.187}{1+28.187(0,1)^{2}} \\
& \mathrm{n}=\frac{28.187}{282,87} \\
& \mathrm{n}=\quad 99,646, \text { dibulatkan menjadi } 100
\end{aligned}
$$

\section{Teknik pengumpulan data}

Teknikpengumpulan data pada penelitian ini memakai kuesioner atau teknik angket. Teknik angket sudah ada pengumpulan data yang berisi pertanyaan tertulis yang ditujukan untuk responden. Survei untuk penelitian ini berupadaftar pertanyaan pada responden tentang persepsi pelaku UKM, pendidikan, pengetahuan akuntansi serta pelatihan akuntansi terhadap penerapan informasi akuntansi UKM.

\section{Teknik analisis data}

Teknik analisis data menggunakan analisis deskriptif, uji hipotesis klasik, analisis regresi berganda, uji koefisien determinasi dan uji t dianalisis menggunakan SPSS versi 21. 


\section{Uji Validitas}

Uji validitas merupakan uji yang bertujuan untuk menilai suatu ukuran dengan mengukur ketetapatan yang harus diukur. Uji validitas ini menggunakan teknik Corrected Item-Total Correlation, yaitu mengkorelasikan skor setiap item pertanyaan menggunakan skor total dan melakukan koreksi terhadap nilai koefisien yang tidak sesuai.

Tabel 1 Hasil Uji Validitas Variabel Penerapan Informasi Akuntansi UKM

\begin{tabular}{|c|c|c|c|c|}
\hline Variabel & Pertanyaan & $\begin{array}{l}\text { Corrected } \\
\text { Item Total } \\
\text { Correlation }\end{array}$ & $\begin{array}{l}\text { Cronbachs } \\
\text { Alpha }\end{array}$ & Ket \\
\hline \multirow{10}{*}{$\begin{array}{l}\text { Penerapan } \\
\text { Informasi } \\
\text { Akuntansi } \\
\text { UKM }\end{array}$} & Y1 & .621 & .738 & Valid \\
\hline & Y2 & .539 & .746 & Valid \\
\hline & Y3 & .633 & .735 & Valid \\
\hline & Y4 & .621 & .730 & Valid \\
\hline & Y5 & .717 & .728 & Valid \\
\hline & Y6 & .691 & .722 & Valid \\
\hline & Y7 & .605 & .734 & Valid \\
\hline & Y8 & .348 & .770 & Valid \\
\hline & Y9 & .554 & .743 & Valid \\
\hline & Y10 &.-313 & .872 & Tidak Valid \\
\hline
\end{tabular}

Sumber: Olahan data primer, 2021

Berdasarkan uji validitas di atas, diperoleh hasil bahwa $r$ hitung lebih besar dari $\mathrm{r}$ tabel. Dan dari hasil diatas, terdapat 1 item pernyataan terkait aplikasi informasi akuntansi yang tidak valid.

Table 2 Hasil Uji Validitas Persepsi Pelaku UKM

\begin{tabular}{|c|c|c|c|c|}
\hline Variable & Pernyataan & $\begin{array}{l}\text { Corrected } \\
\text { Item }\end{array}$ & $\begin{array}{l}\text { Cronbach's } \\
\text { Alpha }\end{array}$ & Ket. \\
\hline \multirow{10}{*}{$\begin{array}{l}\text { Persepsi } \\
\text { Pelaku }\end{array}$} & $\mathrm{X} 1^{\prime 1}$ & .431 & .714 & \multirow{9}{*}{ Valid } \\
\hline & $\mathrm{X} 1^{\prime 2}$ & .364 & .728 & \\
\hline & $\mathrm{X} 1^{\prime 3}$ & .430 & .714 & \\
\hline & $\mathrm{X} 1^{\prime 4}$ & .552 & .692 & \\
\hline & $\mathrm{X} 1^{15}$ & .454 & .710 & \\
\hline & $\mathrm{X} 1^{\prime 6}$ & .627 & .691 & \\
\hline & $\mathrm{X} 1^{, 7}$ & .588 & .687 & \\
\hline & $\mathrm{X} 1^{\prime 8}$ & .284 & .732 & \\
\hline & $\mathrm{X} 1^{\prime 9}$ & .322 & .729 & \\
\hline & $\mathrm{X} 1^{, 10}$ & .168 & .773 & Tidak Valid \\
\hline
\end{tabular}

Sumber: Olahan data primer, 2021

Berdasarkan hasil uji validitas diatas, diperoleh hasil bahwa $r$ hitung lebih besar dari $r$ tabel. Dan dari hasil diatas, diketahui bahwa sada 1 butir pernyataan pada variabel persepsi pelaku UKM dinyatakan tidak valid.

Tabel 3 Hasil UjiValiditas Pendidikan

\begin{tabular}{|c|c|c|c|c|}
\hline Variable & Pernyataan & Correct Item & $\begin{array}{l}\text { Crombach's } \\
\text { Alpha }\end{array}$ & Ket \\
\hline \multirow{6}{*}{ Pendidikan } & $\mathrm{X} 2^{\prime 1}$ & .533 & .881 & \multirow{6}{*}{ Valid } \\
\hline & $\mathrm{X} 2^{, 2}$ & .805 & .836 & \\
\hline & $\mathrm{X} 2^{3}$ & .826 & .833 & \\
\hline & $\mathrm{X} 2^{\prime 4}$ & .800 & .840 & \\
\hline & $X 2^{, 5}$ & .679 & .858 & \\
\hline & $\mathrm{X} 2^{\prime 6}$ & .611 & .864 & \\
\hline
\end{tabular}


Owner: Riset \& Jurnal Akuntansi

e-ISSN : 2548-9224 | p-ISSN : 2548-7507

Volume 6 Nomor 1, Januari 2022

DOI : https://doi.org/10.33395/owner.v6i1.708

\begin{tabular}{|l|l|l|l|l|}
\hline & $\mathrm{X}^{17}$ & .439 & .883 & \\
\hline
\end{tabular}

Sumber: Olahan data primer, 2021

Berdasar hasil uji validitas diatas, diperoleh hasil bahwa $r$ hitung lebih besar dari $r$ table.

Dan dari hasil diatas, diketahui semua butir pernyataan pada variabel pendidikan dinyatakan valid.

Table 4 Hasil Uji Validitas Pengetahuan Akuntansi

\begin{tabular}{|c|c|c|c|c|}
\hline Variable & Pernyataan & Correct Item & $\begin{array}{l}\text { Crombach's } \\
\text { Alpha }\end{array}$ & Ket. \\
\hline \multirow{10}{*}{$\begin{array}{l}\text { Tingkat } \\
\text { Pendidikan }\end{array}$} & $\mathrm{X} 3^{\prime 1}$ & .562 & .862 & \multirow{10}{*}{ Valid } \\
\hline & $\mathrm{X} 3^{, 2}$ & .476 & .867 & \\
\hline & $\mathrm{X} 3^{33}$ & .618 & .857 & \\
\hline & $\mathrm{X} 3^{\prime 4}$ & .650 & .857 & \\
\hline & $\mathrm{X} 3^{\prime 5}$ & .548 & .862 & \\
\hline & $\mathrm{X} 3^{36}$ & .633 & .855 & \\
\hline & $X 3^{, 7}$ & .838 & .837 & \\
\hline & $\mathrm{X} 3^{\prime 8}$ & .731 & .846 & \\
\hline & $\mathrm{X} 3^{\prime 9}$ & .477 & .868 & \\
\hline & $\mathrm{X} 3^{, 10}$ & .408 & .873 & \\
\hline
\end{tabular}

Sumber: Olahan data primer, 2021

Berdasarkan hasil uji validitas diatas dapat diperoleh hasil bahwa $r$ hitung lebih besar dari $\mathrm{r}$ table. Dan dari hasil diatas, diketahui semua butir pernyataan pada variabel pengetahuan akuntansi dinyatakan valid.

Table 5 Hasil Uji Validitas Pelatihan Akuntansi

\begin{tabular}{|c|c|c|c|c|}
\hline Variable & Pernyataan & $\begin{array}{l}\text { Corrected } \\
\text { Item Total } \\
\text { Correlation }\end{array}$ & $\begin{array}{l}\text { Cronbahs's } \\
\text { Alpha }\end{array}$ & Ket \\
\hline \multirow{7}{*}{ Pendidikan } & $\mathrm{X} 4^{\prime 1}$ & .206 & .858 & Tidak Valid \\
\hline & $\mathrm{X} 4^{\prime 2}$ & .498 & .807 & \multirow{6}{*}{ Valid } \\
\hline & $\mathrm{X} 4^{3}$ & .597 & .791 & \\
\hline & $\mathrm{X} 4^{4}$ & .638 & .783 & \\
\hline & $X 4^{\prime 5}$ & .733 & .768 & \\
\hline & $\mathrm{X} 4^{\prime 6}$ & .738 & .768 & \\
\hline & $\mathrm{X} 4^{17}$ & .604 & .790 & \\
\hline
\end{tabular}

Sumber: Olahan data primer, 2021

Berdasarkan hasil uji validitas, dapat diperoleh hasil $r$ hitung lebih besar dari $r$ table. Dan dari hasil diatas, diketahui bahwa item pernyataan nomor 1 nyatakan tidak valid.

\section{Uji Reabilitas}

Uji reliabilitas merupakan penguji yang bertujuan menguji apakah informasi lapangan yg digunakan dapat diandalkan menjadi alat pengumpulan data yang merupakan indikator suatu variabel atau konstruk (Ghozali, 2013). Pengukuran reliabilitas memakai metode titik atau point measure dimana suatu variabel atau konstruk dikatakan reliabel jika menyampaikan nilai Cronbach's Alpha > 0,70. 
Table 6 Hasil Uji Reliabilitas

\begin{tabular}{|c|l|l|l|l|}
\hline No. & Variabel & $\begin{array}{l}\text { Alpha } \\
\text { Cronbach }\end{array}$ & Kriteria & Keterangan \\
\hline 1 & $\begin{array}{l}\text { Penerapan Informasi Akuntansi } \\
\text { UKM }\end{array}$ & .775 & 0.7 & Reliable \\
\hline 2 & Persepsi Pelaku UKM & .738 & 0.7 & Reliable \\
\hline 3 & Tingkat Pendidikan & .875 & 0.7 & Reliable \\
\hline 4 & Pengetahuan Akuntansi & .871 & 0.7 & Reliable \\
\hline 5 & Pelatihan Akuntansi & .821 & 0.7 & Reliable \\
\hline
\end{tabular}

Sumber: Olahan data primer, 2021

Dari table tersebut, hasil yang didapatkan menunjukkan bahwa nilai Cronbach's Alpha semua variabel penelitian lebih besar dari 0.7. Maka dari itu, tanggapan responden terhadap variable-variable ini dapat diandalkan.

\section{Analisis deskriptif}

Statistik deskriptif memiliki tujuan untuk menjelaskan mengenai data per masingmasing variabel dari nilai max,min, mean,median dan standar deviasi.

Gambaran detail data untuk masing-masing variabel dapat dilihat pada tabel berikut ini:

Table 7 Hasil Analisis Statistik Deskriptif

\begin{tabular}{|l|c|l|l|l|l|l|}
\hline \multicolumn{1}{|c|}{ Variable } & n & Minimal & Maksimal & Mean & Med & $\begin{array}{c}\text { Std. } \\
\text { Deviasi }\end{array}$ \\
\hline $\begin{array}{l}\text { Penerapan Informasi } \\
\text { Akuntansi }\end{array}$ & 101 & 20 & 50 & 36.47 & 37.00 & 6.173 \\
\hline Persepsi pelaku UKM & 101 & 20 & 49 & 37.32 & 37.00 & 4.377 \\
\hline Pendidikan & 101 & 20 & 35 & 26.62 & 26.00 & 3.376 \\
\hline Pengetahuan Akuntansi & 101 & 19 & 50 & 32.23 & 31.00 & 7.176 \\
\hline Pelatihan Akuntansi & 101 & 14 & 35 & 22.85 & 23.00 & 5.458 \\
\hline Valid & 101 & & & & & \\
\hline
\end{tabular}

Sumber: Olahan data primer, 2021

\section{Analisis uji normalitas}

Uji normalitas melibatkan pengujian data penelitian dalam model regresi untuk variabel pengganggu atau residual yang memiliki distribusi normal. Dalam penelitian ini menggunakan program SPSS Window seri 21. Menggunakan uji statistik Kolmogoraf Sminorv (K-S). Normal atau tidak pencarian dapat dilihat dari kriteria yang telah ditentukan jika nilai statistik pengujiannya adalah 0,05 , maka data residual berdistribusi normal dan sebaliknya.

Table 8 Hasil Uji Normalitas

\begin{tabular}{|ll|l|}
\hline & $\begin{array}{l}\text { Unstandardized } \\
\text { Residual }\end{array}$ \\
\hline $\mathrm{N}$ & & 101 \\
\hline Normal Parameters(a,b) & Mean & .0000000 \\
\hline & Std. Deviation & 4.35265609 \\
\hline Most Extreme Differences Absolute & Absolute & .095 \\
\hline & Positive & .095 \\
\hline
\end{tabular}


Owner: Riset \& Jurnal Akuntansi

e-ISSN : 2548-9224 | p-ISSN : 2548-7507

Volume 6 Nomor 1, Januari 2022

DOI : https://doi.org/10.33395/owner.v6i1.708

\begin{tabular}{|l|l|}
\hline \multicolumn{1}{|c|}{ Negative } & -.088 \\
\hline Test Statistic & .025 \\
\hline As. Sig. (2-tailed) & $.095^{\mathrm{c}}$ \\
\hline
\end{tabular}

Sumber: Olahan data primer, 2021

Berdasarkan uji normalitas pada Table 8 disimpulkan bahwa nilai probabilitas penelitian ini adalah 0,095 yang lebih besar dari 0,05, sehingga dapat digunakan dalam penelitian karena data berdistribusi normal.

\section{Analisis Uji Multikolineritas}

Uji multikolinearitas memiliki tujuan untuk menguji apakah terdapat pada contoh regresi adanya hubungan antar variabel bebas (independen), untuk tmendeteksi ada tidaknya multikolinearitas dalam regresi memakai nilai toleransi lebih besar asal0,10 atau nilai VIF (Variance Inflation Factor) kurang berasal 10, maka dinyatakan bebas berasal hal multikolinearitas. Kriteriayg digunakan artinya menggunakan menguji nilai variance inflation factor (VIF) dibawah 10 serta nilai toleransi pada di atas 0,1 ,jadi tidak terdapat hubungan multikolinearitas.

Uji multikolinearitas dapat ditinjau di Tabel 9padabawah ini

1Table 9 Hasil Uji Multikolinearitas

\begin{tabular}{|c|c|c|}
\hline \multirow{2}{*}{ Model } & \multicolumn{2}{|c|}{ Collinearity Statistiks } \\
\cline { 2 - 3 } & Tolerance & VIF \\
\hline X1 & .785 & 1.273 \\
\hline X2 & .654 & 1.529 \\
\hline X3 & .398 & 2.511 \\
\hline X4 & .361 & 2.770 \\
\hline
\end{tabular}

Sumber: Olahan data primer, 2021

Berdasarkan hasil uji multikolinearitas yang ditunjukkan pada Tabel 9 dapat disimpulkan bahwa nilai tolerance keempat variabel lebih besar dari 0,10 dan nilai VIF keempat variabel kurang dari 10, sehingga layak untuk digunakan penelitian, karena data tidak menyajikan masalah multikolinearitas.

\section{Uji Heteroskedastisitas}

Uji heteroskedastisitas bertujuan untuk menguji apakah dalam model regresi terdapat ketidaksamaan varians residual dari satu pengamatan ke pengamatan lainnya. Cara mendeteksinya adalah dengan melihat grafik scatterplot, jika tidak ada pola yang jelas dan memanjang di atas dan di bawah angka 0 pada sumbu Y, maka tidak terjadi heteroskedastisitas. Uji heteroskedastisitas dilihat pada Gambar 2 di bawah ini:

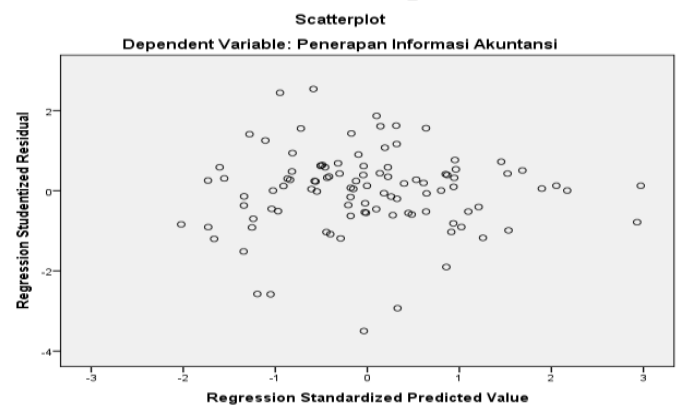

Gambar 2 Hasil Uji Heteroskedastisitas

Sumber: Olahan data primer, 2021 
Berdasarkan hasil uji heteroskedastisitas yang ditunjukkan pada Gambar 2 dapat dilihat bahwa titik-titik berdistribusi secara acak dan terdistribusi baik di atas maupun di bawah angka 0 pada sumbu Y. disimpulkan tidak terjadi heteroskedastisitas.

\section{Uji Hipotesis (Analisis Regresi Berganda)}

Uji Regresi adalah inti dari studi tentang ketergantungan satu atau lebih variabel kebebasan (penjelasan atau perbedaan independensi) dan perbedaan perbedaan (terkait) dengan spesies target estimasi dan/atau estimasi populasi rata-rata atau nilai varians. Karena mengetahui pentingnya kebebasan berbeda-beda. (Gujarati, 2003). Analisis regresi berganda digunakan untuk memperkirakan perbedaan antara dua atau lebih variabel bebas dalam suatu persamaan (Trihendradi, 2009).

Dari berbagai penilaian horizontal persepsi pelaku UKM, pendidikan, pengetahuan akuntansi dan pelatihan akuntansi diperoleh hasil sebagai berikut:

Table 10 Hasil Uji Analisis Regresi

\begin{tabular}{|l|l|l|l|l|l|}
\hline Model & & $\begin{array}{l}\text { Unstandardized } \\
\text { Coefficients }\end{array}$ & Sig. & $\mathrm{t}$ & Kesimpulan \\
\hline & & $\mathrm{B}$ & & & \\
\hline 1 & Cons $)$ & -.375 & .933 & -.084 & \\
\hline & Persepsi pelaku UKM & .281 & .016 & 2.454 & H1 diterima \\
\hline & Tingkat pendidikan & .642 & .000 & 3.948 & H2 diterima \\
\hline & Pemahaman akuntansi & .149 & .132 & 1.521 & H3 tidak diterima \\
\hline & Pelatihan akuntansi & .195 & .154 & 1.436 & H4 tidak diterima \\
\hline
\end{tabular}

Sumber: Olahan data primer, 2020

Daritable10, pada kolom B pada baris pertama menunjukkan konstanta (a) kemudian baris kedua dan seterusnya menunjukkan koefisien variabel bebas yang diteliti. Model regresi yang terbentuk berdasarkan Tabel 4.7 adalah sebagai berikut.

$\mathrm{Y}=-.375+0.281 \mathrm{X} 1+0.281 \mathrm{X} 2+0.149 \mathrm{X} 3+0.195 \mathrm{X} 4$

\section{Analisis Uji Koefisien Determinasi}

Koefisien determinasi (R2) mengukur seberapa baik kemampuan model dalam menjelaskan variasi variabel terikat. Hal ini dapat dilihat dari nilai adjusted $\mathrm{R}$ squared atau R2 untuk mengetahui apakah variabel dependen dapat dijelaskan oleh variabel independen. Nilai R2 yang kecil berarti kemampuan variabel bebas untuk menjelaskan variabel terikat sangat terbatas, sedangkan nilai yang mendekati satu berarti variabel terikat menyediakan hampir semua informasi yang dibutuhkan untuk memprediksi variasi variabel terikat. Berikut adalah hasil uji koefisien determinasi:

Table 11 Hasil Uji Koefisien Determination

\begin{tabular}{|l|l|l|l|l|}
\hline Model & R & R2 & $\begin{array}{l}\text { Adjust } \\
\text { Square }\end{array}$ & Standar Eror \\
\hline 1 & .709 & .503 & .482 & 4.44241 \\
\hline
\end{tabular}

Sumber: Olahan data primer, 2021

Dari Table 11 diperoleh nilai koefisien R squared (R2) sebesar 0,503 atau 50,3\%. Kesimpulannya adalah bahwa variabel bebas dapat menjelaskan penerapan informasi akuntansi karena variabel terikat sebesar $50,3 \%$ dan $49,7 \%$ dijelaskan oleh variabel lain di luar penelitian ini. 


\section{Analisis Uji t}

Uji T-statistik menunjukkan seberapa jauh pengaruh variabel penjelas atau individu independen terhadap penjelasan variasi variabel dependen. Uji hipotesis nol (H0). Hipotesis 1,2,3,4 diuji dengan uji-t, setelah itu ditentukan nilai probabilitas yang diperoleh dari hasil perhitungan. Jika nilai rata-rata berada di bawah taraf signifikansi 0,05, maka asumsi tersebut dianggap signifikan. Sebaliknya, jika signifikansi lebih besar dari 0,05, asumsinya tidak signifikan.

\section{PEMBAHASAN \\ Pengaruh Persepsi Pelaku UKM terhadap Penerapan Informasi Akuntansi UKM}

Berdasarkan hasil uji regresi berganda menjelaskan dalam penelitian ini observasi berpengaruh positif signifikan terhadap penerapan informasi akuntansi, yang ditunjukkan dengan angka t yang lebih tinggi dari t tabel $(2,454>1,98373)$, dan rata-rata 0,016 , yang lebih kecil dari $0,05(0,016<0,05)$. Hasil penelitian ini menemukan bahwa hipotesis pertama (H1) diadopsi untuk menjelaskan bahwa persepsi pelaku UMKM berpengaruh terhadap penerapan informasi akuntansi pada UMKM. lebih kecil dari t tabel, dengan rata-rata 0,007 lebih kecil dari 0,05 berarti $\mathrm{H} 1$ diterima.

\section{Pengaruh Pendidikan terhadap Penerapan Informasi Akuntansi UKM}

Berdasarkan hasil statistik uji regresi berganda dijelaskan hasi; berpengaruh positif dan signifikan terhadap penerapan informasi akuntansi yang ditunjukkan dengan t hitung lebih besar dari t tabel (3.9 $8>1.98373)$, dan nilai signifikansinya sebesar 0,000 . kurang dari $0,05(0,0000>0,05)$. Dari hasil tersebut dapat diartikan bahwa hipotesis kedua $(\mathrm{H} 2)$ diterima sehingga dapat dikatakan bahwa pencapaian pendidikan berpengaruh terhadap penerapan informasi akuntansi.

\section{Pengaruh Pengetahuan Akuntansi terhadap Penerapan Informasi Akuntansi UKM}

Dilihat dari analisis statistik uji regresi berganda yang dilakukan dalam penelitian ini, ditemukan bahwa pengetahuan akuntansi tidak berpengaruh signifikan terhadap penggunaan informasi akuntansi UKM, yang diwakili oleh $t$ lebih kecil dari $t$ tabel $(1,521$ $<1,98373)$, dan rata-rata 0,132 . lebih besar dari 0,05 $(0,132>0,05)$. Hasil penelitian menunjukkan bahwa hipotesis ketiga (H3) tidak diterima, sehingga dapat dikatakan bahwa pengetahuan akuntansi tidak berpengaruh terhadap penerapan informasi akuntansi.

\section{Pengaruh Pelatihan Akuntansi terhadap Penerapan Informasi Akuntansi UKM}

Dilihat dari hasil statistik dari berbagai uji yang dilakukan, penelitian ini menemukan bahwa pendidikan akuntansi tidak berpengaruh signifikan terhadap penggunaan informasi akuntansi, dibuktikan dengan nilai t-hitung yang lebih rendah dari pada Tabel $\mathrm{t}(1.436)$. <1,98373) dan nilai mean sebesar 0,154 $(0,154>0,05)$ lebih besar dari 0,05. Dari hasil tersebut dapat diartikan bahwa pelatihan akuntansi tidak berpengaruh terhadap penerapan informasi akuntansi pada UKM karena hipotesis pertama (H4) tidak diterima.

\section{KESIMPULAN}

Variabel yang mempunyai pengaruh positif signifikan terhadap penerapan informasi akuntansi di Kabupaten Banjarnegara adalah variabel persepsi pelaku UKM dan tingkat pendidikan. Artinya, makin tinggi persepsi pelaku UKM dan tingkat pendidikan maka akan makin tinggi penerapan informasi akuntansi UKM di Kabupaten Banjarnegara.

Variabel yang tidak memiliki pengaruh yang signifikan terhadap penerapan informasi akuntansi UKM di Kabupaten Banjarnegara adalah variabel pengetahuan akuntansi dan pelatihan akuntansi. Hal tersebut menjelaskan bahwa rendahnya pengetahuan akuntansi dan pelatihan akuntansi tidak memengaruhi penerapan informasi akuntansi UKM di Kabupaten Banjarnegara. 


\section{REFERENSI}

Andrades, J., Martinez-martinez, D., \& Larran, M. (2019). Determinants of information disclosure by Spanish state-owned enterprises in accordance with legal requirements. Journal of Cleaner Production, Vol 39, pp 60-72.

Biadacz, R. (2021), Quality cost management in the SMEs of Poland, The TQM Journal, Vol. 33 No. 7, pp. 1-38.

Dewi Mekarsari dan Isniati Hidayah. (2019). Potret UMKM Indonesia: Sikecil yang Berperan Besar. ukmindonesia.id/baca-artikel/62.

Diyana, I. Y. F. (2017). Analisis Pengelolaan Keuangan Usaha Mikro Kecil Dan Menengah. Skripsi. Yogyakarta: Fakultas Ekonomi Universitas Sanata Dharma.

Efriyenty, Dian. (2020). Analisis Faktor-Faktor Yang Memengaruhi Penggunaan Informasi Akuntansi Pada Umkm Kota Batam. Jurnal Bisnis Terapan, Vol 4 No 1 Surabaya: Politeknik Ubaya.

Gilan, Irwan. (2020). Teori Keputusan: Cara Mengambil Keputusan Bisnis. glngirwn.com/blog/teori-keputusan/.

Ghozali I dan Chariri, A. (2014). Teori Akuntansi. Semarang: Badan Penerbit Universitas Diponegoro.

Ghozali I \& Chariri, A. (2013). Aplikasi Analisis Multivariate dengan Program IBM SPSS 21. Semarang: Badan Penerbit Universitas Diponegoro.

Hani, S \& Fauzi, Z. Persepsi Pelaku Ukm Terhadap Penyelenggaraan Laporan Keuangan . Jurnal Akuntansi, Keuangan dan Perpajakan Indonesia,Vol 5 No. 2.

Huerta, E., Petrides, Y. \& O'Shaughnessy, D. (2017). Introduction of accounting practices in small family businesses. Journal of Qualitative Research in

Accounting \& Management, Vo. 14 No. 2, pp 111-136.

Jordão, R.V.D. \& Novas, J.C. (2017), Knowledge management and intellectual capital in networks of small- and medium-sized enterprises, Journal of Intellectual Capital, Vol 18 No 3, 667-692.

Jordão, R.V.D., Novas, J. and Gupta, V. (2020), "The role of knowledge-based networks in the intellectual capital and organizational performance of small and medium-sized enterprises", Kybernetes, Vol. 49 No. 1, pp. 116-140.

Juita, V. (2016). Pemanfaatan Sistem Informasi Akuntansi Pada Usaha Mikro, Kecil, Dan Menengah (Umkm) Sektor Jasa Perdagangan Di Padang, Sumatera Barat. Jurnal Riset Akuntansi Terpadu, Vol 9 No 1.

Lestari, Dwi. (2015). Pengaruh Pengetahuan Akuntansi, Pengalaman Usaha, Dan Motivasi Kerja Terhadap Persepsi Penggunaan Informasi Akuntansi Pada Pelaku Umkm Di Boyolali. Jurnal Pendidikan Akuntansi, Yogyakarta: Universitas Negeri Yogyakarta.

Mouti, D.A.(2020) Pengaruh Persepsi Pemilik Dan Pengetahuan Akuntansi Pelaku Usaha Barbershop Terhadap Penggunaan Informasi Akuntansi. Skripsi. Yogyakarta: Fakultas Ekonomi dan Bisnis Universitas Pembangunan Nasional Veteran .

Mulyani, A.S. (2018). Manfaat Informasi Akuntansi Dalam Perkembangan Usaha Mikro Kecil dan Menengah. Journal Ecodomica,Vol 2 No 1.

Mulyani, A.S, Nurhayati, E \& Miharja, K. Penerapan Pencatatan dan Laporan Akuntansi Pada Usaha Mikro Kecil dan Menengah (UMKM). Jurnal Abdimas BSI, Vol 2 No 2.

Mustaqhfiroh. (2016). Faktor Penentu Penggunaan Informasi Akuntansi Pada Usaha Kecil Dan Menengah Dengan Good Corporate Governance Sebagai Variabel Intervening. Skripsi. Semarang: Fakultas Ekonomi UNNES.

Nabawi, I.N. (2017). Analisis Faktor-Faktor Yang Mempengaruhi Penggunaan Informasi Akuntansi Pada Usaha Mikro Kecil Dan Menengah Di Kota Yogyakarta. Skripsi. 
Yogyakarta: Universitas Islam Indonesia.

Najera Ruiz, T. and Collazzo, P. (2021), "Management accounting use in micro and small enterprises", Qualitative Research in Accounting \& Management, Vol. 18 No. 1, pp. 84-101.

Novianti, D, Mustika, I.W \& Eka, L.H. (2018). Pengaruh Tingkat Pendidikan, Pelatihan Akuntansi, Umur Usaha Dan Skala Usaha Pelaku Umkm Terhadap Penggunaan Informasi Akuntansi Di Kecamatan Purwokerto Utara. Jurnal Ekonomi, Bisnis dan Akuntansi, Vol 20 No 3 Purwokerto: Universitas Jenderal Soedirman.

Rahmawati, E.T, Subagyo, S \& Budiadi, D. (2019). Implementasi Penggunaan Sistem Informasi Akuntansi Umkm Dalam Menghadapi Revolusi Industri 4.0. Journal of Business, Economic and Accounting, Vol 9 No 2.

Ritchi, H., Azis, Y., Adrianto, Z., Setiono, K. and Sanjaya, S. (2020), "In-app controls for small business accounting information system: a study of domain understanding", Journal of Small Business and Enterprise Development, Vol. 27 No. 1, pp. 31-51.

Sabri, M. (2018). Tinjauan Economic Entity Concept Berdasarkan Spiritual Capital dalam Pengelolaan Keuangan Usaha Mikro. Skripsi.Makassar: Fakultas Ekonomi dan Bisnis Universitas Islam Negeri Alauddin Makassar.

Savitri, R.V. (2018). Pencatatan Akuntansi Pada Usaha Mikro Kecil Dan Menengah. Jurnal Manajemen Bisnis dan Inovasi, Vol 5 No 2.

Setyawati, Y \& Hermawan, S. (2018). Persepsi Pemilik Dan Pengetahuan Akuntansi Pelaku Usaha Mikro Kecil Dan Menengah (Umkm) Atas Penyusunan Laporan Keuangan. Riset Akuntansi dan Keuangan Indonesia, Vol 3 No 2 Sidoarjo: Universitas Muhammadiyah Sidoarjo. 